\title{
Economic Rebalancing and Electricity Demand in China
}

\begin{abstract}
As China undertakes a transition to a more consumption- and service-oriented economy, electricity consumption in the richest provinces has been plateauing. Though projections for electricity use in 2030 range widely from 5,308 to 8,292 $\mathrm{kWh}$ per capita, most results suggest that policymakers and power system planners seriously re-evaluate the need for new generation capacity to avoid overinvestment that could lead to stranded generation assets.
\end{abstract}

Jiang Lin ${ }^{\mathrm{a}}$, Gang $\mathrm{He}^{\mathrm{b}}$ and Alexandria Yuan ${ }^{\mathrm{c}}$

Jiang Lin is Senior Vice President, China Strategy and Analysis, at the Energy

Foundation.

Gang He is an Assistant Professor of energy policy in the Department of Technology and Society, College of Engineering and Applied Sciences, Stony Brook University.

Alexandria Yuan is a master student in Goldman School of Public Policy, University of California - Berkeley.

The authors would like to thank Lynn Price, Nan Zhou, and David Fridley for their comments. The work described in this article was supported by Energy Foundation China through the U.S. Department of Energy under Contract No. DE-AC02-05CH11231.

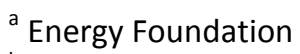

${ }^{\mathrm{b}}$ Stony Brook University

c University of California - Berkeley
} 


\section{Introduction}

Over the last three decades, China's economy has grown on average close to $10 \%$ per year. As a result, China's power system has grown 22.7 times in capacity from $60 \mathrm{GW}$ in 1980 to $1,360 \mathrm{GW}$ in 2014, and electricity consumption has grown 18.7 times from 295 TWh in 1980 to 5,523 TWh in 2014, or 9\% per year (CEC, 2015). However, China's economy has recently entered into a "new normal" phase of transition and rebalancing, featuring slower growth in general, and moving from a growth model driven by investment and exports to one driven by consumption and a larger share of services in the economy (Green and Stern, 2015; Xi, 2014; Zhang, 2015). As such, energy and electricity use have seen much slower growth in the past two years. For the first time, coal use declined in 2014 and electricity use has been growing at its slowest pace in recent years, up only $0.6 \%$ in the first half of 2015 (NEA, 2015).

China's electricity demand experienced several boom and bust cycles, which were fairly consistent with economic cycles in the last 25 years. The last major downturn was associated with the Asian financial crisis in 1998, when the electricity growth rate dropped to $3.1 \%$. During the global financial crisis of 2008, electricity growth rate reached $6 \%$, partly due to the huge stimulus package the Chinese government instituted at the time to mitigate the economic downturn.

The growth rate of electricity consumption in 2014 reached a low of 3.8\%; the last time electricity growth was this low was 1998. The year-on-year electricity growth rate in the first half of 2015 was reported to be only $0.6 \%$ (NEA, 2015). Electricity elasticity in 2014 also reached a historic low since 1998 at 0.51 . While the growth rate of electricity consumption may rebound if economic growth picks up in the future, these recent data, as well as the ongoing economic transition, suggest that a new lower-growth phase with lower elasticity may be emerging for electricity demand growth in China (Figure 1). 


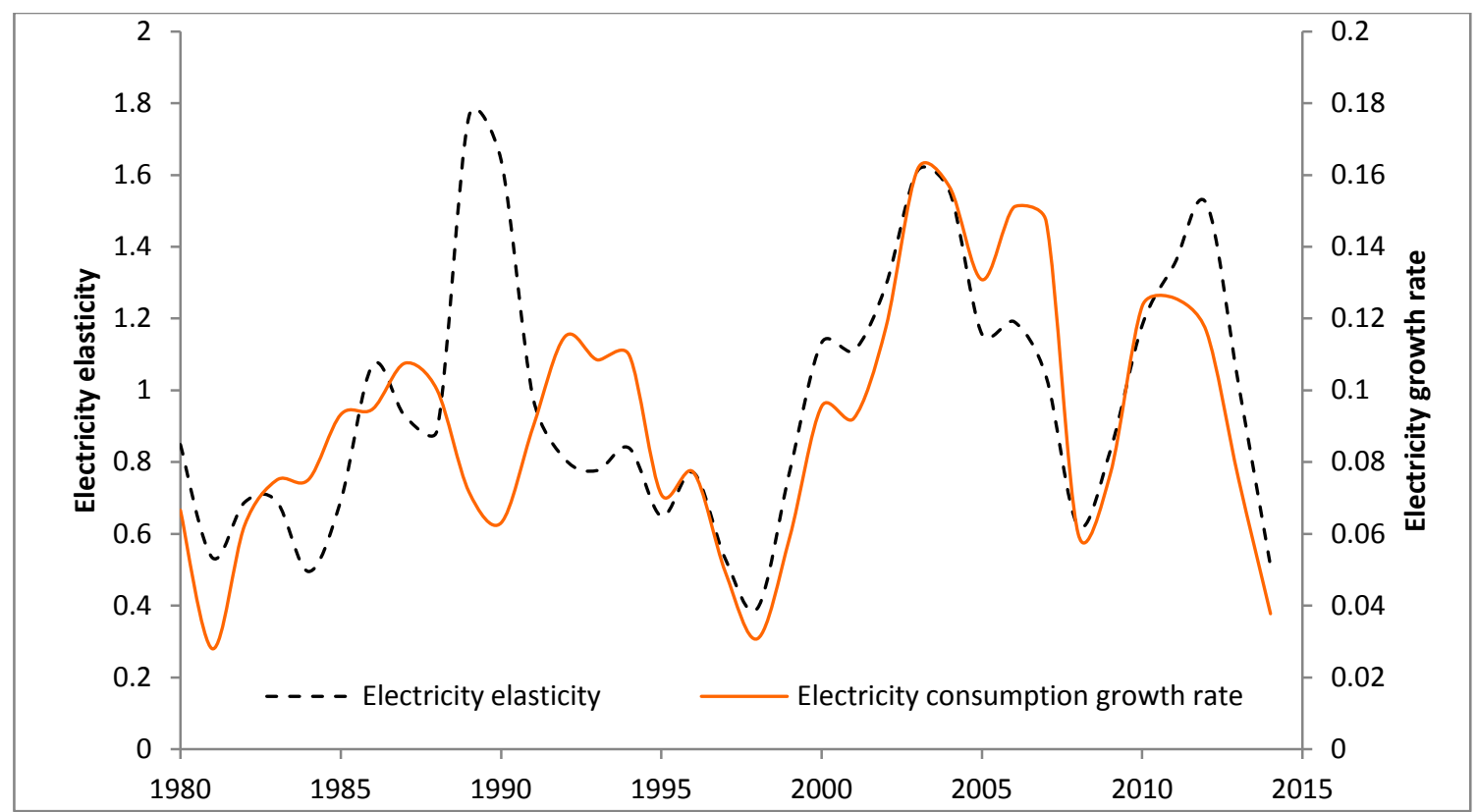

Figure 1 Electricity consumption growth rate and electricity elasticity in China, 1980-

2014(World Bank, 2015)

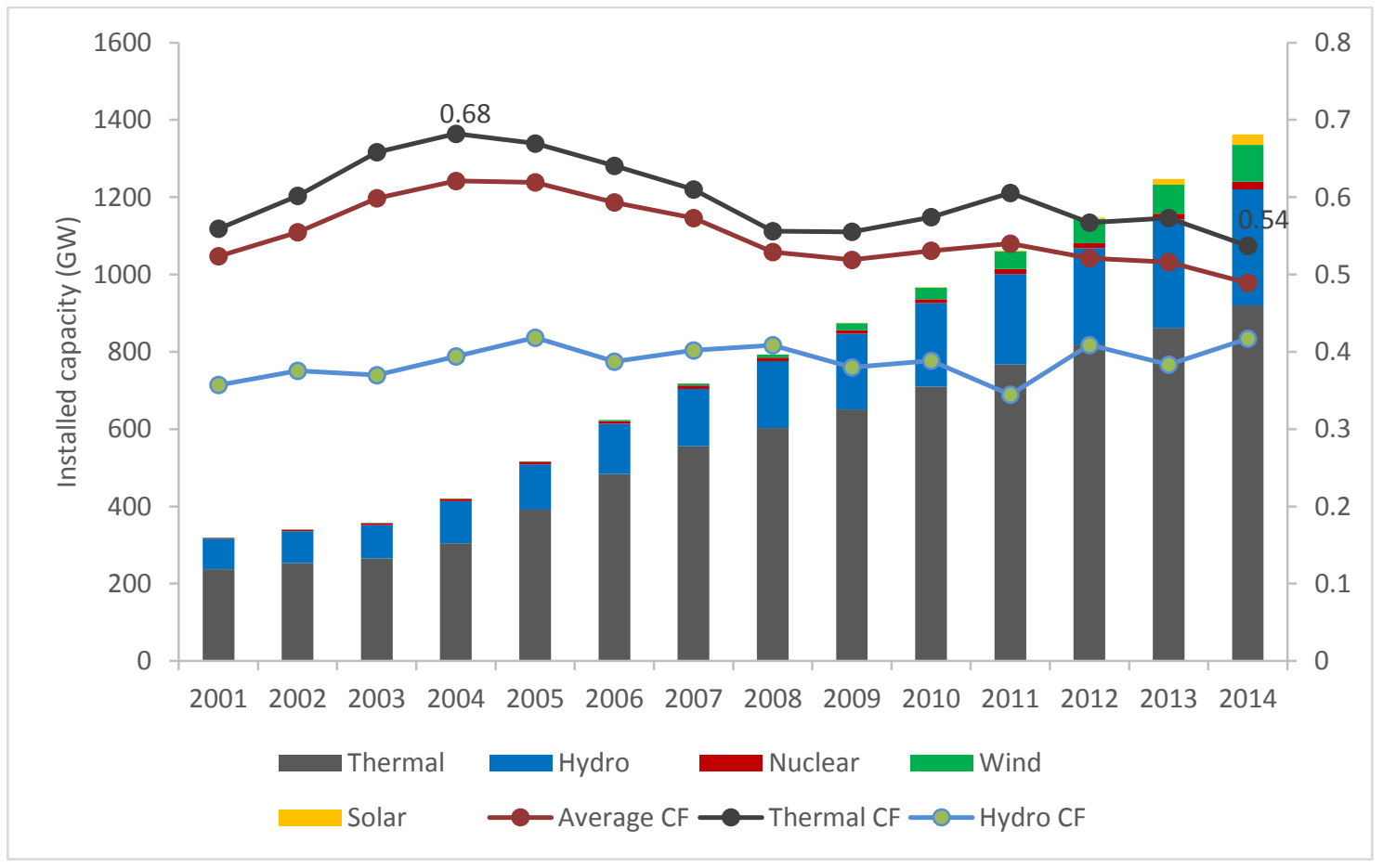

Figure 2 Average annual capacity factor and total installed capacity by technology 
In addition, the average capacity factors of China's power plants have been decreasing generally since 2004, from a peak of 0.62 in 2004 to 0.49 in 2014 (Figure 2), the lowest since 1978 (CEC, 2015). China's installed power capacity has been dominated by thermal plants, which in 2014 accounted for $67 \%$ of its total $1,360 \mathrm{GW}$ of capacity and generated $75 \%$ of total electricity production (CEC, 2015). In 2014, 95\% of thermal capacity was coal-fired, with the balance being natural gas.

The increase in capacity installation has recently overtaken the growth of electricity demand. Over the past decade, the rapid expansion of thermal plants, which are usually run as base load, has led to overcapacity of baseload plants, and the expansion of other competitive power sources such as wind, solar, and nuclear has result in lower capacity factors for existing plants - indicating that the current baseload assets are not fully utilized (Figure 2).

Annual investment in thermal power capacity has been decreasing, while that in other generation capacity has been expanding since the 2000s. Thermal capacity investment decreased by 50\% from 2006 to 2013, while that for solar has grown 12 times, wind 10 times, and nuclear 7 times during the same period. In 2008, investment in non-fossil generation capacity, including nuclear and renewables, surpassed that of thermal generation capacity, and 2013 saw more new non-fossil capacity brought on line than thermal capacity (Wei, 2014). As the additional electricity demand will increasingly be met by non-fossil generation - as China strives to meet its $20 \%$ non-fossil energy target by 2030 - a continued high level of expansion of coal power plants could result in overcapacity and stranded investments. 
Regional disparities appear in the national general trend. China is a big country and the regional economic development is highly imbalanced. This can be observed in Figure 3, which shows provincial economic development (real GDP per capita) and electricity consumption (electricity consumption per capita). The data in Figure 3 suggest that Chinese provinces can be categorized into three groups. The first group is composed of Shanghai, Tianjin, and Beijing, high-income municipalities with GDP per capita higher than around 70,000 RMB (about $\$ 11,000$ ); for these municipalities, the growth of per capita electricity consumption appears to have plateaued. Qinghai, Xinjiang, Inner Mongolia, Shaanxi, Shanxi, and Ningxia are in a second group, with comparatively lower GDP per capita but high per-capita electricity consumption, as they are mostly energy extractive provinces with extensive heavy industry. The third group is composed of provinces that fall between these high and low groupings related to per capita income and electricity use. 


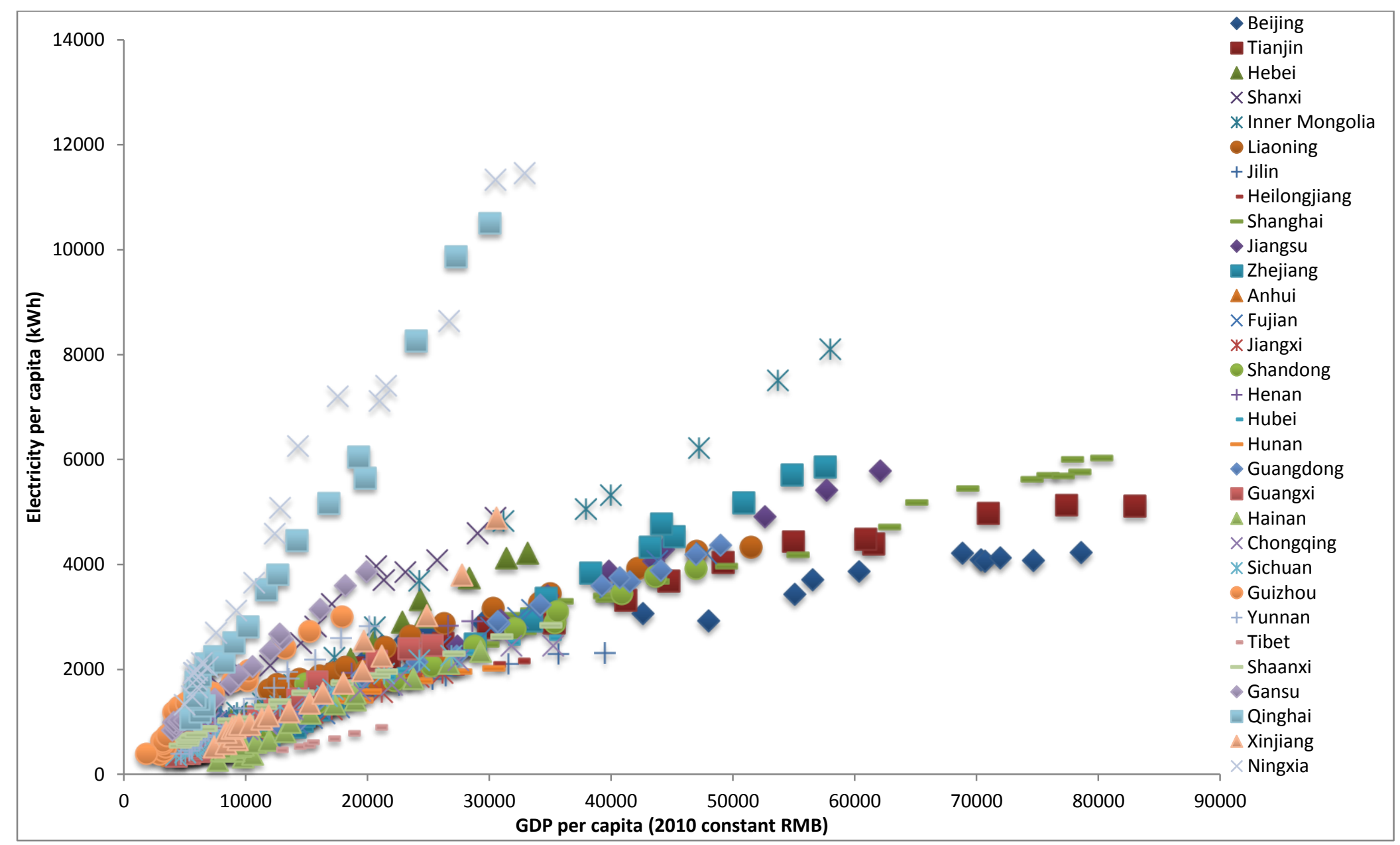

Figure 3 Relationship between electricity consumption and real GDP per capita by province 
Even so, many Chinese and international institutions still project fast growth in electricity use (Hu et al., 2011; Jiang et al., 2013; Wang and Watson, 2010). Figure 4 provides the electricity projections of three recent studies: the International Energy Agency's World Energy Outlook 2014 (IEA 2014), the 2050 China Economic Development and Electricity Demand Study by the Intelligent Laboratory for EconomyEnergy-Electricity-Environment, ILE4 (Hu, Tan, and Xu 2011), and the Energy Research Institute's China 2050 High Renewable Energy Penetration Scenario and Roadmap Study (ERI, 2015). In these studies, China's electricity consumption in 2030 is projected to range from 7,584 TWh ( $\sim 5830 \mathrm{kWh}$ per capita) to $11,154 \mathrm{TWh}(\sim 8580 \mathrm{kWh}$ per capita).

As the Chinese economy matures, it is important to understand whether such a conventional perspective that China will maintain a high rate of GDP growth with a high elasticity of electricity demand still holds. In this article, we explore an alternative model in which electricity use will decelerate relative to economic growth and this relationship will continue to fall over time as the Chinese economy shifts to less energy-intensive sectors, and consumption behaviors start to change. Further, we examine the regional pattern of electricity usage to understand the differences among regions in China, as well as use these data to test various relationships between income, economic structure, and electricity use. 


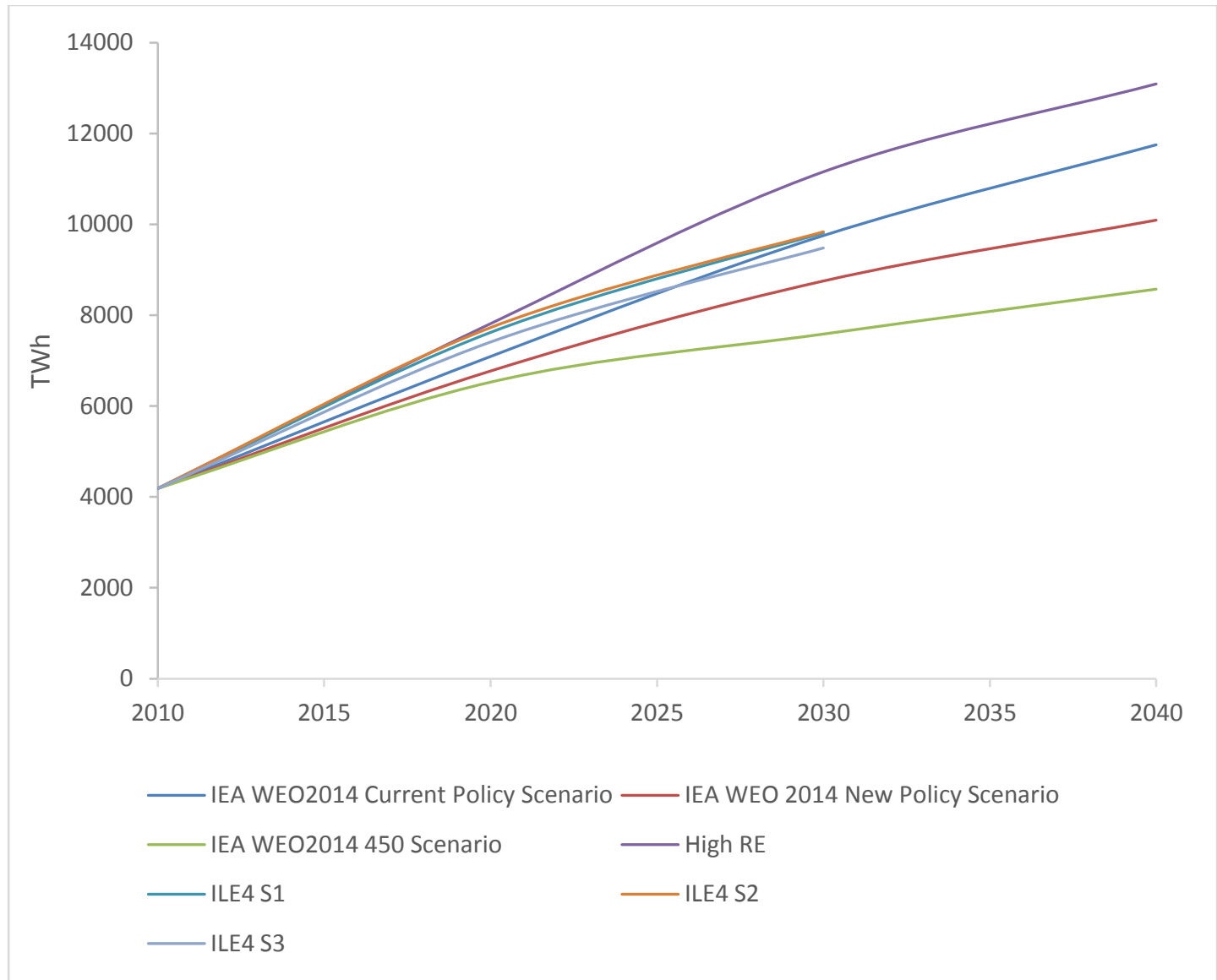

Figure 4 Recent projections of China's electricity demand

Note: S1, S2, S3 are three scenarios presented by ILE4 (Hu et al., 2011). The IEA and High RE reports only provide electricity generation; we subtract transmission and distribution losses (6\% assumed) and import/export balances which are negligible in China (ERI, 2015; Hu et al., 2011; IEA, 2014).

\section{Literature review}

Understanding the relationship between energy—more specifically electricity—and economic development is essential and a component of long-term strategic planning (Smil, 2000; Stern and Cleveland, 2004; WEF and IHS, 2013). However, identifying the relationship between electricity consumption and economic development is difficult 
given the complex underlying behavioral and structural mechanisms, especially technology, market liberalization, and sustainable development (Tremblay, 1994).

There is extensive literature regarding the relationship between electricity consumption and economic growth, with varying regional or national focuses. Generally, studies have found that there could be either a unidirectional relationship from electricity consumption to economic growth, or bidirectional, or even non-causal relationship between electricity consumption and economic growth (Altinay and Karagol, 2005; Asafu-Adjaye, 2000; Ghosh, 2002; Squalli, 2007; Wang et al., 2011; Wolde-Rufael, 2006; Yoo, 2006, 2005; Yoo and Kwak, 2010).

For China-specific studies, Shiu and Lan (2004) applied an error-correction model to study the causal relationship between electricity consumption and real GDP in China, and found there is a unidirectional relationship running from electricity consumption to real GDP, which means electricity consumption drives economic growth, but not the reverse (Shiu and Lam, 2004). Additionally, Yuan et al. (2007) applied the co-integration theory and indicated that there exists Granger causality, a predictive causality, running from electricity consumption to GDP, but such causality does not exist from GDP to electricity consumption (Yuan et al., 2007). However, these studies are based on data from earlier periods that may not offer observations that reflect the recent developments in Chinese electricity use and GDP growth.

Given the advances in energy efficiency and renewable energy technologies, as well as the growing concern over energy-related greenhouse gas (GHG) emissions, some have questioned the assumption of a continuing close link between growth in energy consumption and economic development, and have proposed that a sufficient living 
standard could be maintained without significantly increasing per-capita energy use. Experts have suggested that 1 kilowatt per capita is sufficient to support basic human needs with an emphasis on energy efficiency improvement and modern energy carriers (Goldemberg et al., 1985). This concept was further developed by the Board of the Swiss Federal Institutes of Technology, and followed by the Swiss Advisory Committee for Energy Research to achieve a "2 kW society" in Switzerland by 2050 (Haldi and Favrat, 2006). If a complete "decoupling" - that is, maintaining a continued economic well-being with a fixed level of energy or electricity use - is achieved, then future growth in energy or electricity use would taper down over time. In fact, such a decoupling is close to being achieved in some developed regions; for example, California has able to hold per capita electricity use essentially constant since the 1970s (Rosenfeld and Poskanzer, 2009) and the U.S. as a whole has also entered a new reality of lower growth rate in electricity consumption (Hirsh and Koomey, 2015).

\section{III.Methodology and data}

This article uses 20 years of provincial level GDP and electricity consumption data in China to test the statistical relationships between per capita income and electricity consumption, then projects three scenarios of electricity demand with models derived from the observed data. We argue that the linear model, often adopted by conventional studies, deserves reassessment.

The assumption is that electricity consumption is a function of income and economic structure. To smooth out the impact of population, we use electricity consumption per capita, GDP per capita to represent income levels, and the share of tertiary GDP to 
represent economic structure. We choose three approaches to estimate the relationship between electricity consumption, income, and economic structure.

The linear model:

$$
E_{c a p}=a G D P_{c a p}-b \text { Tertiary }+c
$$

The polynomial model:

$$
E_{c a p}=a G D P_{c a p}-b\left(G D P_{c a p}\right)^{2}-c \text { Tertiary }+d
$$

The logarithmic model:

$$
\ln E_{c a p}=a \ln G D P_{c a p}-b \text { Tertiary }+c
$$

Where:

$\mathrm{E}_{\text {cap }}$ is the electricity consumption per capita; $\mathrm{GDP}_{\text {cap }}$ is the real GDP per capita at 2010 constant RMB value; Tertiary is the share of tertiary GDP (point) in total GDP.

The purpose of this analysis is not to identify the best model for capturing the causal relationships but rather to provide alternative modeling approaches that could shed light on the evolving nature of these relationships. We are testing the hypothesis that the relationship between electricity consumption per capita and GDP per capita is evolving as China's economy is shifting to a different phase of growth based on our observation of a plateau effect in China's per capita electricity consumption in high-income provinces. This observation leads us to question the assumption in conventional demand projections using linear extrapolation to project future energy and electricity consumption. We have 
chosen to test two additional functional forms to explore whether these alternatives better explain the evolving relationship between electricity and GDP per capita in China.

The electricity consumption data are extracted from the China Energy Statistical Yearbook, and the population, GDP, and tertiary GDP share data are from the China Statistical Yearbook. All data are reported at the provincial level from 1990 to 2012. The real GDP deflator is obtained from the World Bank GDP deflator database (World Bank, 2015).

\section{IV.Results}

The regression results of the three models — linear, polynomial, and logarithmic — are shown below and are summarized in Table 1. There is a positive correlation between electricity consumption per capita and GDP per capita, and the coefficients are statistically significant at a $1 \%$ level. There is a negative correlation between electricity consumption per capita and tertiary GDP share, and the coefficients are statistically significant at a $1 \%$ level in the linear and polynomial model, and $10 \%$ level in the logarithmic model.

Linear model:

$$
E_{\text {cap }}=0.0836 G D P_{\text {cap }}-29.37 \text { Tertiary }+1546
$$

Polynomial model:

$$
E_{\text {cap }}=0.133 G D P_{\text {cap }}-7.67 E(-7)\left(G D P_{\text {cap }}\right)^{2}-20.77 \text { Tertiary }+733.4
$$

Logarithmic model:

$$
\ln E_{\text {cap }}=0.836 \ln G D P_{\text {cap }}-0.00520 \text { Tertiary }-0.467
$$


Table 1 The effect of GDP per capita and tertiary GDP share on electricity consumption per capita

\begin{tabular}{|c|c|c|c|}
\hline \multirow[t]{2}{*}{ VARIABLES } & (1) Linear & (2) Polynomial & (3) Logarithm \\
\hline & $\begin{array}{c}\text { Electricity } \\
\text { Consumption per } \\
\text { capita }\end{array}$ & $\begin{array}{c}\text { Electricity } \\
\text { Consumption per } \\
\text { capita }\end{array}$ & $\begin{array}{c}\text { Log electricity } \\
\text { Consumption per capita }\end{array}$ \\
\hline \multirow[t]{2}{*}{ GDP per capita } & $0.0836 * * *$ & $0.133 * * *$ & \\
\hline & $(0.00413)$ & $(0.0106)$ & \\
\hline \multirow[t]{2}{*}{ GDP per capita square } & & $-7.67 \mathrm{e}-07 * * *$ & \\
\hline & & $(1.32 \mathrm{e}-07)$ & \\
\hline \multirow[t]{2}{*}{ Tertiary GDP share } & $-29.37 * * *$ & $-20.77 * * *$ & $-0.00520^{*}$ \\
\hline & $(8.344)$ & $(7.369)$ & $(0.00291)$ \\
\hline \multirow[t]{2}{*}{ Log GDP per capita } & & & $0.836 * * *$ \\
\hline & & & $(0.0317)$ \\
\hline \multirow[t]{2}{*}{ Constant } & $1,546 * * *$ & $733.4 * * *$ & $-0.467^{*}$ \\
\hline & $(276.2)$ & $(239.1)$ & $(0.238)$ \\
\hline Observations & 540 & 540 & 540 \\
\hline R-squared & 0.528 & 0.554 & 0.662 \\
\hline Adjusted R-squared & 0.526 & 0.551 & 0.661 \\
\hline RMSE & 1133 & 1102 & 0.414 \\
\hline \multicolumn{4}{|c|}{ Robust standard errors in parentheses } \\
\hline$* * * \mathrm{p}<0.01, * * \mathrm{p}<0.05$ & & & \\
\hline
\end{tabular}

We can see that the logarithmic and polynomial models fit the historical data better than the linear model as evidenced by a higher R-squared. Applying the GDP level and tertiary GDP share level projected by the World Bank (World Bank, 2013), and using population data given by United Nations to calculate the projected GDP per capita, the 
projected electricity consumption per capita of three different models is calculated in Table 2 and plotted in Figure 5.

Table 2 Electricity consumption per capita under three different projections

\begin{tabular}{|c|c|c|c|c|c|}
\hline Period & & 2011-15 & 2016-20 & 2021-25 & $2026-30$ \\
\hline $\begin{array}{c}\text { GDP growth rate (percent } \\
\text { per year) }\end{array}$ & & 8.6 & 7.0 & 5.9 & 5.0 \\
\hline Year & 2010 & 2015 & 2020 & 2025 & 2030 \\
\hline GDP (trillion 2010RMB) & 40.15 & 60.65 & 85.07 & 113.30 & 144.61 \\
\hline Population (million) & 1340 & 1376 & 1402 & 1414 & 1415 \\
\hline $\begin{array}{c}\text { GDP per capita } \\
(2010 \mathrm{RMB})\end{array}$ & 32765 & 44079 & 60676 & 80130 & 102196 \\
\hline Tertiary GDP share (\%) & 43.24 & 47.60 & 51.60 & 56.10 & 61.10 \\
\hline $\begin{array}{l}\text { Electricity per capita } \\
\text { (Linear) }(\mathrm{kWh})\end{array}$ & 3015 & 3833 & 5100 & 6593 & 8292 \\
\hline $\begin{array}{l}\text { Electricity per capita } \\
\text { (Poly) (kWh) }\end{array}$ & 3370 & 4117 & 4906 & 5300 & 5308 \\
\hline $\begin{array}{c}\text { Electricity per capita (Log) } \\
\qquad(\mathrm{kWh})\end{array}$ & 2981 & 3735 & 4776 & 5886 & 7032 \\
\hline
\end{tabular}

Source: 2010 GDP data is from China Statistic Yearbook 2014. GDP growth rate and tertiary GDP share are from World Bank, 2013, China 2030. Population projection is from UN World Population Prospects: The 2015 Revision, in the medium variant scenario. GDP per capita is calculated based on GDP and population data.

Using the polynomial model, we find that electricity consumption per capita in China would peak in 2026 at 5,308 kWh when GDP hits 84,030 RMB and tertiary GDP share accounts for $57.1 \%$, which China would achieve based on the World Bank's projections of GDP growth rate and tertiary GDP share. As we haven't observed any decrease of per capita electricity consumption globally, we assume per capita electricity consumption will stabilize after the peak in the polynomial model. The electricity consumption per capita is projected to be $8,292 \mathrm{kWh}$ and $7,030 \mathrm{kWh}$ in 2030 , respectively, using the linear model and logarithm models, which are 2,984 $\mathrm{kWh}$ and 1,722 $\mathrm{kWh}$ higher than that in the polynomial model. 
We find that there is evidence to support that a "new normal relationship" on electricity use is emerging, and that per capita electricity usage may plateau or peak around 2030. However, under different models of estimation, the level of plateau electricity use in China could differ substantially, by as much as 56\%. This could have significant implications for power system planning, investment, and operations in China. If the power system planning approach is not responsive to these emerging trends, there is a significant chance of overbuilding the power capacity in China, with hundreds of billions of dollars of investment potentially stuck as stranded assets.

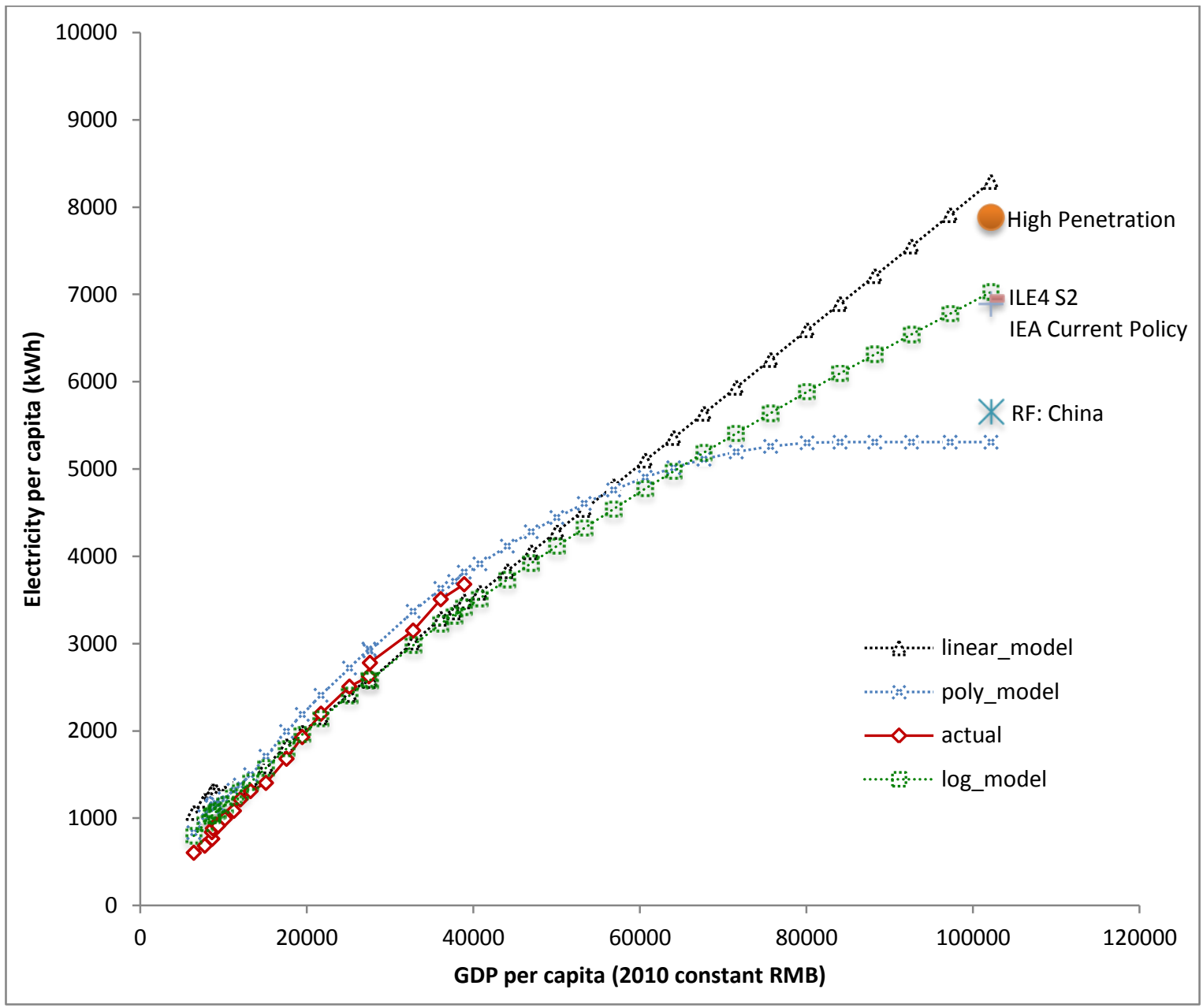

Figure 5 Projections of electricity consumption per capita at different GDP per capita levels 


\section{Conclusion and policy implications}

This study uses 20 years of provincial GDP and electricity consumption data to reexamine the relationship between these two factors in China. We observe a plateauing effect of electricity consumption per capita in high-income provinces as China's economy develops and moves to a more service-based economy. Data presented in Figure 3 suggest that the relationship between per capita electricity consumption and economic development is evolving to a new stage, and that per capita electricity demand is growing only moderately in most Chinese provinces, or even plateauing in the most developed regions, with the exception of a few energy extractive provinces. Using different functional forms, as well as comparing with a few other recent sources, there is a wide range of projections, ranging from 5,308 to $8,292 \mathrm{kWh}$ electricity per capita in 2030 (Table 3).

Table 3 Projected per capita electricity use in China in 2030

\begin{tabular}{|l|c|c|c|c|l|l|}
\hline Model & Linear & Logarithm & Polynomial & BNEF & 2050 High & RF \\
\hline Electricity per cap & 8292 & 7030 & 5308 & 6270 & 7883 & China \\
$(\mathrm{kWh})$ & & & & & & \\
\hline
\end{tabular}

Source: BNEF and 2050 High RE (BNEF, 2013); 2050 High RE refers to the 2050 High Renewable Energy

Penetration Scenario study by Energy Research Institute (ERI, 2015); RF China refers to Reinventing Fire:

China, which a joint study by China’s Energy Research Institute, Lawrence Berkeley National Laboratory, and Rocky Mountain Institute that has not been published as of this writing. 
While these different studies have different modeling techniques and inputs, some of the notable difference is likely due to different assumptions used. For instance, in the 2050 High Renewable Scenario, the assumed electrification rate is much higher than that in RF China. However, from a policy planning and investment perspective, such wide variation in projected electricity use raises a serious question about the evolving nature of the relationship between electricity use and economic development. If electricity demand is assumed to grow linearly with GDP, future demand may be seriously overstated, leading to hundreds of billions of dollars of stranded investment.

Despite slowing demand, investment in coal power plants remained robust in the first half of 2015. It is estimated that, by 2030, China's power system will grow by another 1,000 to $1,200 \mathrm{GW}$ in capacity (BNEF, 2015). China's National Center for Climate Change Strategy and International Cooperation (NCSC) estimated 900 GW additional non-fossil capacity is needed between 2014 and 2030 (Fu et al., 2015). Given China's 2030 goal of achieving a $20 \%$ share of non-fossil energy, most of the new additions will be renewables or nuclear. It is therefore critically important to assess the evolving relationship between electricity use and economic development, as China transitions to a new growth phase that is likely to be less energy and resource intensive. Policymakers and power system planners can use the observations of this study to reevaluate power demand projections and reexamine the generation capacity expansion plans so as to avoid over investment and stranded assets. 


\section{References}

Altinay, G., Karagol, E., 2005. Electricity consumption and economic growth: Evidence from Turkey. Energy Econ. 27, 849-856. doi:10.1016/j.eneco.2005.07.002

Asafu-Adjaye, J., 2000. The relationship between energy consumption, energy prices and economic growth: time series evidence from Asian developing countries. Energy Econ. 22, 615-625. doi:10.1016/S0140-9883(00)00050-5

BNEF, 2013. The future of China's power sector: from centralised and coal powered to distributed and renewable? Bloomberg New Energy Finance.

CEC, 2015. The current status and prospect of China's power industry. China Electricity Council, Beijing.

ERI, 2015. China 2050 high renewable energy penetration scenario and roadmap study. Energy Research Institute, Beijing.

Fu, S., Zou, J., Liu, L., 2015. Comments on China's INDC. National Center for Climate Change Strategy and International Cooperation, Beijing.

Ghosh, S., 2002. Electricity consumption and economic growth in India. Energy Policy 30, 125129. doi:10.1016/S0301-4215(01)00078-7

Goldemberg, J., Johansson, T.B., Reddy, A.K.N., Williams, R.H., 1985. Basic Needs and Much More with One Kilowatt per Capita. Ambio 14, 190-200.

Green, F., Stern, N., 2015. China's "new normal": structural change, better growth, and peak emissions. Centre for Climate Change Economics and Policy, Grantham Research Institute on Climate Change and the Environment, London.

Haldi, P.-A., Favrat, D., 2006. Methodological aspects of the definition of a $2 \mathrm{~kW}$ society. Energy, ECOS 2004 - 17th International Conference on Efficiency, Costs, Optimization, Simulation, and Environmental Impact of Energy on Process Systems 17th International Conference on Efficiency, Costs, Optimization, Simulation, and Environmental Impact of Energy on Process Systems 31, 3159-3170. doi:10.1016/j.energy.2006.02.011

Hirsh, R.F., Koomey, J.G., 2015. Electricity Consumption and Economic Growth: A New Relationship with Significant Consequences? Electr. J. 28, 72-84. doi:10.1016/j.tej.2015.10.002

Hu, Z., Tan, X., Xu, Z., 2011. 2050 China Economic Development and Electricity Demand Study. China Electric Power Press, Beijing.

IEA, 2014. World Energy Outlook 2014. Organisation for Economic Co-operation and Development, Paris.

Jiang, K., Zhuang, X., Miao, R., He, C., 2013. China's role in attaining the global $2^{\circ} \mathrm{C}$ target. Clim. Policy 13, 55-69. doi:10.1080/14693062.2012.746070

NEA, 2015. National Energy Administration releases the national energy situation in the first half of 2015 [WWW Document]. URL http://www.nea.gov.cn/2015-07/27/c_134450600.htm

Rosenfeld, A.H., Poskanzer, D., 2009. A Graph Is Worth a Thousand Gigawatt-Hours: How California Came to Lead the United States in Energy Efficiency (Innovations Case Narrative: The California Effect). Innov. Technol. Gov. Glob. 4, 57-79. doi:10.1162/itgg.2009.4.4.57

Shiu, A., Lam, P.-L., 2004. Electricity consumption and economic growth in China. Energy Policy 32, 47-54. doi:10.1016/S0301-4215(02)00250-1

Smil, V., 2000. Energy in the Twentieth Century: Resources, Conversions, Costs, Uses, and Consequences. Annu. Rev. Energy Environ. 25, 21-51. doi:10.1146/annurev.energy.25.1.21

Squalli, J., 2007. Electricity consumption and economic growth: Bounds and causality analyses of OPEC members. Energy Econ. 29, 1192-1205. doi:10.1016/j.eneco.2006.10.001 
Stern, D.I., Cleveland, C.J., 2004. Energy and Economic Growth (Rensselaer Working Papers in Economics). Rensselaer Polytechnic Institute, Department of Economics.

Tremblay, M.T., 1994. Energy consumption and economic development.

Wang, S.S., Zhou, D.Q., Zhou, P., Wang, Q.W., 2011. CO2 emissions, energy consumption and economic growth in China: A panel data analysis. Energy Policy 39, 4870-4875. doi:10.1016/j.enpol.2011.06.032

Wang, T., Watson, J., 2010. Scenario analysis of China's emissions pathways in the 21 st century for low carbon transition. Energy Policy 38, 3537-3546. doi:10.1016/j.enpol.2010.02.031

WEF, IHS, 2013. Energy for Economic Growth: Energy Vision Update 2012. World Economic Forum.

Wei, S., 2014. China Electric Power Yearbook 2014. China Electric Power Press, Beijing.

Wolde-Rufael, Y., 2006. Electricity consumption and economic growth: a time series experience for 17 African countries. Energy Policy 34, 1106-1114. doi:10.1016/j.enpol.2004.10.008

World Bank, 2015. World Bank Data [WWW Document]. URL http://data.worldbank.org/country/china

World Bank, 2013. China 2030 : building a modern, harmonious, and creative society (No. 76299). The World Bank.

Xi, J., 2014. Building Asia Pacific dream to seek sustainable development. Peoples Dly.

Yoo, S.-H., 2006. The causal relationship between electricity consumption and economic growth in the ASEAN countries. Energy Policy 34, 3573-3582. doi:10.1016/j.enpol.2005.07.011

Yoo, S.-H., 2005. Electricity consumption and economic growth: evidence from Korea. Energy Policy 33, 1627-1632. doi:10.1016/j.enpol.2004.02.002

Yoo, S.-H., Kwak, S.-Y., 2010. Electricity consumption and economic growth in seven South American countries. Energy Policy 38, 181-188. doi:10.1016/j.enpol.2009.09.003

Yuan, J., Zhao, C., Yu, S., Hu, Z., 2007. Electricity consumption and economic growth in China: Cointegration and co-feature analysis. Energy Econ. 29, 1179-1191. doi:10.1016/j.eneco.2006.09.005

Zhang, Z., 2015. China Economic New Normal. People's Press, Beijing. 